\title{
Effects of Industry Type on ICT Adoption among Malaysian SMEs
}

\author{
Khong Sin Tan ${ }^{1}$, Uchenna Cyril Eze ${ }^{1}$, and Siong Choy Chong ${ }^{2}$ \\ ${ }^{1}$ Multimedia University, Malacca, Malaysia \\ ${ }^{2}$ Putra International College, Malacca, Malaysia
}

\begin{abstract}
Information and Communications Technology (ICT) has been widely regarded as an enabler to boost the competitive level of SMEs in the business arena. Notwithstanding the many efforts undertaken by governments to promote ICT adoption among SMEs across different types of industries, many of them failed to reap this benefit evenly. This problem is prevalent among the SMEs in the Asia Pacific region and Malaysia is no exception. This paper therefore investigates industry types as a moderating factor that may exert significant effects on the adoption of ICT among SMEs in Malaysia. Based on the extended Diffusion of Technology Innovation model, a questionnaire-based survey was conducted on 406 managers/owners of SMEs in the southern region of Malaysia. The findings suggest that different type of SMEs do affect the strength relationship between some predictor variables and ICT adoption intention. The findings are discussed and interpreted to provide key implications to the policy makers in general and the SMEs in particular.
\end{abstract}

Keywords: ICT Adoption, UTAUT Model, Small and Medium Enterprises, Malaysia

\section{Introduction}

There appears to be general consensus that Internet-based Information and Communications Technology (ICT) adoption can bring enormous benefits to the small and medium enterprises (SMEs) either as producers and/or users of ICT. These advantages include supporting business transformation, closer working relationship among value chain partners, increased productivity, enhanced efficiency, greater access to market information and knowledge, and more importantly, the ability to reach new clients from either locally, regionally or globally (Abouzeedan and Busler, 2002; Kotelnikov, 2007; Tornatzky and Klein, 1982).

Therefore, their abilities to put in place the right processes and tools through making decisions on information technology (IT) adoption would place them in an advantageous position of executing and achieving their business strategies and targets as well as to respond effectively and efficiently to market changes.

As such, ICT adoption has been recognised as a key pillar of success of this segment, more so in view of the important role of SMEs as the economic backbone of many economies. In Malaysia, SMEs accounted for $99.2 \%$ or 518,996 of total business establishments, out of which 448,931 or $86.5 \%$ are service SMEs which include the ICT industry (NSDC, 2005). Large companies only comprise of $0.8 \%$ or 4,136 of all establishments in the country. The SMEs, on an overall, are contributing to about $32 \%$ of the country's annual gross domestic product (GDP) and employ $61.5 \%$ of the labour force, which translates to about 5.6 million job opportunities. Its importance is elevated when the government expects the contribution of the SMEs to increase to $37 \%$, its share of total exports to $22 \%$ (Leong

Copyright (C) 2012 Khong Sin Tan, Uchenna Cyril Eze, and Siong Choy Chong. This is an open access article distributed under the Creative Commons Attribution License unported 3.0, which permits unrestricted use, distribution, and reproduction in any medium, provided that original work is properly cited. Contact author Khong Sin Tan e-maill: kstan@mmu.edu.my 
and Wong, 2007) and to provide job opportunities to 6.2 million people by 2010 .

Realizing the importance of this segment towards the prosperity of the nation and the various benefits brought about by ICT adoption, the Malaysian government has rendered serious attention since the Seventh Economic Plan (1996-2000) on developing and strengthening its ICT infrastructure in order to create an environment conducive for the growth of SMEs and entrepreneurs. One of the grand initiatives undertaken was the establishment of the National IT Council (NITC) in 1994 primarily to formulate and implement the national IT agenda in order to expedite the transformation process from an industrial society to an advanced information and knowledge-based society by bypassing developed society, a vision that the country wishes to achieve in the year 2020. In addition, the Multimedia Super Corridor was conceptualised in 1996 to expedite the transformation process.

Soft loans, grants and incentives are channeled towards the SMEs through government, government agencies such as the Small and Medium Industries Development Corporation (SMIDEC) and financial institutions in order to enhance the growth of these enterprises. For example, the Finance Ministry has recently announced a RM1.2 billion financing facility for SMEs, out of which RM700 million is allocated for modernisation purpose, while the remaining is allocated for SMEs to upgrade their equipment and to modernise operations, including the use of ICT in their business operations. Another organisation, the MCA ICT Resource Centre (MIRC) was established to assist the SMEs to improve their businesses and leverage on the use of ICT solution and advanced business processes that enable them to remain competitive in this era of globalisation (Raj, 2007). The MIRC provides significant help to the SMEs in terms of technical assistance and ICT infrastructure setup. In summary, ICT adoption has been determined as the turning point for many innovative Malaysian SMEs to enhance their competitive level in the market.

However, notwithstanding the various benefits of ICT adoption and incentives provided by the government, its agencies and financial institutions, Malaysian SMEs might be apprehensive towards adopting ICT. They might face major constraints such as poor infrastructure, limited knowledge of ICT, high costs of investment, and probably ignorance on the usefulness of technology. These barriers are in fact found to be prevalent among the SMEs of developed countries as well (Duan et. al., 2002; Fink and Disterer, 2006; Gharavi et. al., 2004). At the same time, Kotelnikov (2007) observes that not all SMEs need to adopt ICT tools to the same degree of sophistication as different industries use ICT differently and thus will adopt it at different pace. For example, the SMEs involved in the manufacturing sector may adopt more complex tools than the service-based SMEs such as the enterprise resource planning or inventory management software. It is against this backdrop that this study aims to investigate industry types as the moderating effect influencing the diffusion of technological innovation and ICT adoption among the SMEs. The findings of this paper will help Malaysian government identify appropriate measures to assist SMEs from different industry types in adopting ICT. Thus, Malaysian government would achieve Vision 2020. The next section reviews literature pertinent to this study.

\section{Literature Review}

\section{Diffusion of Technology Innovation (DOI)}

Introduced by Rogers (1983), the Diffusion of Technology Innovation (DOI) is used to describe the patterns of technological innovation adoption, explain the mechanism and assist in predicting whether and how a new invention will be successful. In short, DOI is concerned with the manner in which new technological ideas migrate from creation to use [47].

Roger (1983) proposes five perceived characteristics of innovation in his DOI model which consists of relative advantage, compatibility, complexity, trialability and observability. As shown in Table 3, many researchers have adopted this model along with its characteristics to study the diffusion of innovation. 
Table 3: Constructs and Examples of Research Conducted Using the DOI Model

\begin{tabular}{|l|l|}
\hline Constructs & Reseachers \\
\hline Relative Advantage & $\begin{array}{l}\text { Allan et. al. (2003), Asia Foundation (2002), Carter and Belanger (2004), } \\
\text { Rashid and Al-Qirim (2001), Rogers (1983), Tan et. al. (2009a), Tan et. } \\
\text { al. (2009b), Tan et. al. (In Press), Tan et. al. (2008), Tornatzky and Klein } \\
\text { (1982) }\end{array}$ \\
\hline Compatibility & $\begin{array}{l}\text { Allan et. al. (2003, Benham and Raymond (1996), Carter and Belanger } \\
\text { (2004), Limthongchai and Speece (2003), Rashid and Al-Qirim (2001), } \\
\text { Slegers and Hall (1998), Tan et. al. (2009a), Tan et. al. (2009b), Tan et. al. } \\
\text { (In Press), Tan et. al. (2008), Tan and Teo (2000), Tornatzky and Klein } \\
\text { (1982) }\end{array}$ \\
\hline Trialability & $\begin{array}{l}\text { Benham and Raymond (1996), Kendall et. al. (2001), Khalifa and Cheng } \\
\text { (2002), Rogers (1983), Tan et. al. (2009a), Tan et. al. (2009b), Tan et. al. } \\
\text { (In Press), Tan et. al. (2008), Tan and Teo (2000) }\end{array}$ \\
\hline Observability & $\begin{array}{l}\text { Kogilah et. al. (2008), Rogers (1983), Slegers et. al. (1998), Tan et. al. } \\
\text { (2009a), Tan et. al. (2009b), Tan et. al. (In Press), Tan et. al. (2008) }\end{array}$ \\
\hline Complexity & $\begin{array}{l}\text { Allan et. al. (2003), Carter and Belanger (2004), Cooper and Zmud } \\
\text { (1990), Gharavi et. al. (2004), McCloskey (2004), Rashid and Ai-Qirim } \\
\text { (In Press), Tan et. al. (2008) }\end{array}$ \\
\hline
\end{tabular}

Tan and colleagues (Tan. et. al., 2009a, Tan. et. al., 2009b, Tan and Eze, 2008) provide interesting observations in their research concerning the constructs and applications of DOI. The DOI remains a popular model in investigating diffusion of innovation across different industries (Kendall et. al., 2001; Limthongchai and Speece, 2003). Many researchers tend to combine the constructs of various models to investigate the behaviour of users in adopting new technological innovation, particularly the Theory of Reasoned Action, Theory of Planned Behaviour and the Technology Acceptance Model (Benham \& Raymond, 1996; Limthongchai and Speece, 2003, Tan and Teo, 2000). More interestingly, different results were derived at from the studies based upon the interests of the researchers. Tan and colleagues further observe that even studies using DOI alone yielded different results, particularly on the issues of interest to this research (Kendall et. al., 2001; Limthongchai and Speece, 2003) although the countries investigated share close geographical proximity with Malaysia.

In addition, many studies have adopted security (Aljitri et. al., 2003; Allan et. al., 2003; Beale, 1999; Bhimani, 1996; Kogilah et. al., 2008; Levy et. al., 2005; Light, 2001, Limthongchai and Speece, 2003 ; McCloskey, 2004; Mendo and Fitzgerald, 2005; Ratnasingam, 2001; Rose et. al., 1999; Tan et. al., 2009a; Tan et. al., 2009b; Tan and Eze, 2008; Yeung et. al, 2003) and/or costs (Allan et. al., 2003; Ernst and Young, 2001; Gharavi and Cheng, 2004; Hill and Jones, 2001;
James, 2003; Levy and Worrall, 2005; OECD, 2000; Sambrook, 2003; Tan et. al., 2009a, Tan et. al., 2009b; Tan et. al., In Press; Tan et. al., 2008; Yeung etl al., 2003) as additional measures of evaluating new technological innovations. As such, these measures are incorporated into the study along with the five characteristics of the DOI model.

\section{ICT Adoption}

Rogers (1983) defines adoption as a decision to make full use of an innovation as the best course of action whereas rejection is a decision not to adopt an available innovation. In the context of this study, adoption is defined as the decision by the SMEs to use ICT to communicate and/or conduct businesses with stakeholders. In contrast, rejection means decision not to adopt ICT in business operations of the SMEs.

\section{Industry Types}

Industry types remain one of the popular constructs in examining technological adoption intention (Allan et. al., 2003; Rashid and AiQirim, 2001; Yeung et. al., 2003). It has been identified that both the industry types (manufacturing and service) express intention to adopt ICT, with the service-based SMEs demonstrates greater intention (Tan et. al., In Press). However, the moderating effect of industry types on diffusion of technological innovation and ICT adoption remains to be discovered, which presents a significant gap in knowledge. This is the primary objective of this study. 


\section{Development of Research Model and Research Hypotheses}

\section{Research Framework}

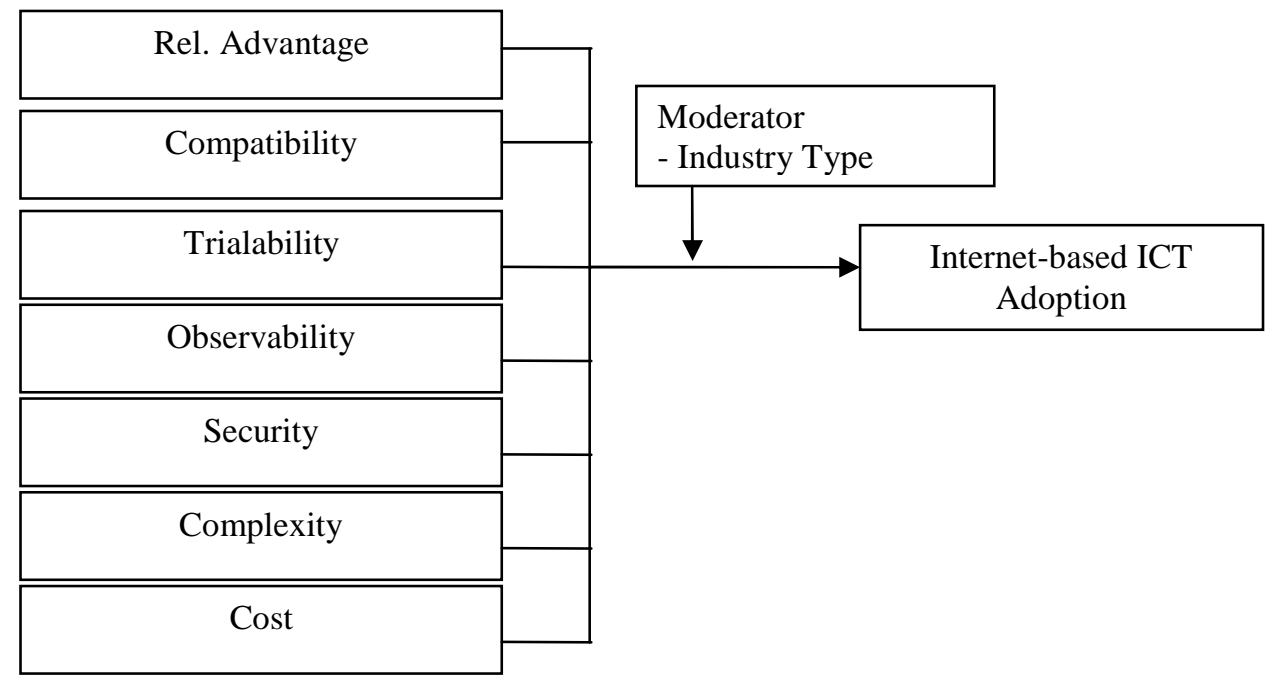

Fig 1. Research Framework

Figure 1 illustrates the resulting research framework based on the extensive review of literature.

Previous scholars have investigated industry type on ICT adoption. Yeung et. al. (2003) conducted a survey among Hong Kong SMEs by separating SMEs into service and manufacturing companies and size of companies. They found that large enterprises have adopted e-commerce application for daily business activities but small and medium- sized enterprises still lag behind. Shiels et. al. (2003) studied the implications of ICT adoption from Europe SMEs by case study and highlighted that characteristics of firm and industry sector are contributory factors to the extent of adoption and exploitation of ICTs by SMEs to support business processes. Bradford and Florin (2003) studied innovation diffusion factors in enterprise resource planning system by considering organisational characteristics such as type of industry, experience with ERP, and size of employees.

Based upon the research framework and objective of this study, the following hypotheses are proposed:

- H1: Industry type does not significantly moderate the relationship between relative advantage and ICT adoption
- H2: Industry type does not significantly moderate the relationship between compatibility and ICT adoption

- H3: Industry type does not significantly moderate the relationship between trialability and ICT adoption

- H4: Industry type does not significantly moderate the relationship between observability and ICT adoption

- H5: Industry type does not significantly moderate the relationship between complexity and ICT adoption

- H6: Industry type does not significantly moderate the relationship between security and ICT adoption

- H7: Industry type does not significantly moderate the relationship between cost and ICT adoption

The next section presents the methodology employed in this study.

\section{Research Methodology}

The study considers SMEs in the southern region of Peninsular Malaysia only, namely the states of Melaka and Johor. There are 75,735 or 
$14.6 \%$ of SMEs are located in this region (National SME Council, 2006).

The list of SMEs was obtained from the SMIDEC's website and filtered to include only SMEs from these two states. Using cluster sampling, every third consecutive company in the list is contacted by phone to request for permission to participate in this study. This explanatory survey considers only owners and/or managers of these enterprises since they oversee the entire operations of their firms and therefore, they are in better positions to understand the future trend and strategies of their enterprises. Upon receiving their consents, questionnaires with self-stamped envelope are sent to them.

The questionnaire consists of three sections. Section one contains demographic information of the SMEs in which type of industry is one of the questions asked. Section two comprises of 42 items measuring the seven characteristics of diffusion of innovation, using a 6-point Likert scale ranging from $1=$ strongly disagree to $6=$ strongly agree which were drawn from literature reviews and prior surveys. Section three has a question on the timeframe of ICT adoption with responses ranging from $1=$ More than 6 years, $2=$ Next 5-6 years, $3=$ Next 4-5 years, $4=$ Next 2-3 years, $5=$ Use within next 1 year and $6=$ Current.

Following the advice by Cooper and Schindler (2003), the questionnaire was piloted on 25 owners and/or managers of SMEs in Melaka so as to establish face validity. The seven characteristics have Cronbach Alpha values of between 0.74 and 0.86 (Table 5), exhibiting a fairly high degree of consistency. Further, the factor analysis results (Table 6) explain $62 \%$ of the variances associated with the seven characteristics, implying an acceptable degree of construct validity. With eigenvalues greater than 1.0 , none of the attributes are dropped and all of them loaded in their respective dimensions.

Table 5: Coefficient Alpha Values and Number of Items for Constructs

\begin{tabular}{|l|c|c|}
\hline Variables & \multicolumn{1}{|l|}{ Alpha } & \multicolumn{1}{l|}{ Items } \\
\hline Relative Advantage & 0.8046 & 6 \\
\hline Compatibility & 0.8496 & 6 \\
\hline Trialability & 0.7406 & 4 \\
\hline Observability & 0.8115 & 6 \\
\hline Complexity & 0.8328 & 5 \\
\hline Security & 0.8134 & 4 \\
\hline Cost & 0.8136 & 4 \\
\hline ICT Adoption & 0.8604 & 7 \\
\hline
\end{tabular}

Table 6: Total Variance Explained

\begin{tabular}{|l|c|c|c|c|c|c|}
\hline \multirow{2}{*}{ Factor } & \multicolumn{3}{|c|}{ Initial Eigenvalues } & \multicolumn{3}{c|}{ Extraction Sums of Squared Loadings } \\
\cline { 2 - 7 } & Total & \% of Var. & Cum. \% & Total & \% of Var. & Cum. \% \\
\hline 1 & 9.097 & 25.992 & 25.992 & 8.685 & 24.814 & 24.814 \\
\hline 2 & 3.992 & 11.405 & 37.397 & 3.644 & 10.413 & 35.226 \\
\hline 3 & 2.569 & 7.340 & 44.737 & 2.124 & 6.067 & 41.294 \\
\hline 4 & 2.017 & 5.764 & 50.501 & 1.682 & 4.805 & 46.099 \\
\hline 5 & 2.505 & 4.301 & 54.802 & 1.920 & 3.166 & 49.265 \\
\hline 6 & 1.345 & 3.843 & 58.645 & 1.188 & 2.629 & 51.894 \\
\hline 7 & 1.176 & 3.360 & 62.005 & 1.020 & 2.142 & 54.036 \\
\hline 8 & 1.150 & 3.285 & 65.290 & .722 & 1.863 & 56.099 \\
\hline 9 & 1.064 & 3.040 & 68.329 & .605 & 1.729 & 57.828 \\
\hline
\end{tabular}

KMO $=0.851$, Bartlett's Test of Sphericity $=7606.262, p=0.000$ 
A total of 406 owners and/or managers agree to participate in the survey, out of which 237 or $58.4 \%$ of the SMEs are from the state of Johor and the remaining SMEs are from Melaka. The sample size is considered adequate since Sekaran (2003) opines that only 384 samples are required for a population of 1 million.

The next section presents the results of the study.

Table 7: Industry Type with Relative Advantage Models

\section{Data Analyses}

Table 7 indicates that industry type does not moderate the relationship between relative advantage and ICT adoption, in view of the pvalue of Model 3 which is greater than 0.05 . Similarly, no significant association is found between relative advantage and ICT adoption. $\mathrm{H} 1$ is accepted.

\begin{tabular}{|c|c|c|c|c|c|c|c|}
\hline \multirow[t]{2}{*}{ Model } & \multirow[t]{2}{*}{$\mathbf{R}$} & \multirow[t]{2}{*}{ R Sqr. } & \multirow[t]{2}{*}{ Adj. R Sqr. } & \multirow{2}{*}{$\begin{array}{l}\text { Std. Err. of } \\
\text { the Est. }\end{array}$} & \multicolumn{3}{|c|}{ Change Statistics } \\
\hline & & & & & $\begin{array}{c}\text { R Sqr. } \\
\text { Chg }\end{array}$ & F Chg & Sig. F Chg \\
\hline 1 & $.831(\mathrm{a})$ & .691 & .691 & .52959 & .691 & 904.915 & .000 \\
\hline 2 & $.832(b)$ & .692 & .691 & .52936 & .001 & 1.348 & .246 \\
\hline 3 & $.832(\mathrm{c})$ & .693 & .691 & .52955 & .001 & .703 & .402 \\
\hline
\end{tabular}

a Predictors: (Constant), Relative advantage,

b Predictors: (Constant), Relative advantage, Industry Type

c Predictors: (Constant), Relative advantage, Industry Type, Interaction

Table 8 shows that although no significant association was found between compatibility and ICT adoption, industry type does moderate the relationship between compatibility and ICT adoption. The p-value of Model 3 indicates that the interaction has contributed $1.1 \%$ of the variance in ICT adoption. The result is further supported by Model 3 in Table 9 . H2 is rejected.

Table 8: Industry Type with Compatibility Models

\begin{tabular}{|c|c|c|c|c|c|c|c|}
\hline Model & R & R Sqr. & \multirow{2}{*}{$\begin{array}{c}\text { Adj. R } \\
\text { Sqr. }\end{array}$} & $\begin{array}{c}\text { Std. Err. of } \\
\text { the Est. }\end{array}$ & \multicolumn{3}{|c|}{ Change Statistics } \\
\cline { 6 - 8 } & & & & & R Sqr. & F & Sig. F Chg. \\
\hline 1 & $.551(\mathrm{a})$ & .303 & .301 & .79578 & .303 & 175.699 & .000 \\
\hline 2 & $.555(\mathrm{~b})$ & .308 & .305 & .79386 & .005 & 2.952 & .087 \\
\hline 3 & $.565(\mathrm{c})$ & .319 & .314 & .78841 & .011 & 6.595 & .011 \\
\hline
\end{tabular}

a Predictors: (Constant), Compatibility

b Predictors: (Constant), Compatibility, Industry Type

c Predictors: (Constant), Compatibility, Industry Type, Interaction

Table 9: Coefficients(a) of Industry Type with Compatibility Models

\begin{tabular}{|c|l|c|c|c|c|c|}
\hline Model & & \multicolumn{2}{|c|}{ Unstd. Coeff. } & Std. Coeff. & t & Sig. \\
\hline & & B & Std. Errr & Beta & & \\
\hline 1 & (Constant) & 2.423 & .152 & & 15.958 & .000 \\
\hline & Compatibility & .509 & .038 & .551 & 13.255 & .000 \\
\hline 2 & (Constant) & 2.343 & .158 & & 14.797 & .000 \\
\hline & Compatibility & .506 & .038 & .547 & 13.171 & .000 \\
\hline & Industry Type & .143 & .083 & .071 & 1.718 & .087 \\
\hline 3 & (Constant) & 1.857 & .246 & & 7.543 & .000 \\
\hline & Compatibility & .636 & .063 & .687 & 10.025 & .000 \\
\hline & Industry Type & .913 & .311 & .456 & 2.935 & .004 \\
\hline
\end{tabular}

a Dependent Variable: ICT Adoption Intention

Table 10 indicates that industry type does not moderate trialability on ICT adoption although significant association was found between trialability and ICT adoption. H3 is accepted. 
Table 10: Industry Type with Trialability Models

\begin{tabular}{|c|c|c|c|c|c|c|c|}
\hline \multirow[t]{2}{*}{ Model } & \multirow[t]{2}{*}{$\mathbf{R}$} & \multirow[t]{2}{*}{ R Sqr. } & \multirow{2}{*}{$\begin{array}{l}\text { Adj. R } \\
\text { Sqr. }\end{array}$} & \multirow{2}{*}{$\begin{array}{c}\text { Std. Err. } \\
\text { of the Est. }\end{array}$} & \multicolumn{3}{|c|}{ Change Statistics } \\
\hline & & & & & $\begin{array}{c}\text { R Sqr. } \\
\text { Chg. }\end{array}$ & $\begin{array}{c}\text { F } \\
\text { Chg. }\end{array}$ & Sig. F Chg. \\
\hline 1 & $.075(\mathrm{a})$ & .006 & .003 & .95053 & .006 & 2.306 & .130 \\
\hline 2 & $.135(\mathrm{~b})$ & .018 & .013 & .94573 & .012 & 5.109 & .024 \\
\hline 3 & $.136(c)$ & .019 & .011 & .94669 & .000 & .184 & .668 \\
\hline
\end{tabular}

Table 11 indicates that industry type does not moderate observability on ICT adoption, neither does a significant association exists between observability and ICT adoption. H4 is accepted.

Table 11: Industry Type with Observability Models

\begin{tabular}{|c|c|c|c|c|c|c|c|}
\hline \multirow[t]{2}{*}{ Model } & \multirow[t]{2}{*}{$\mathbf{R}$} & \multirow[t]{2}{*}{ R Sqr. } & \multirow{2}{*}{$\begin{array}{c}\text { Adj. R } \\
\text { Sqr. }\end{array}$} & \multirow{2}{*}{$\begin{array}{l}\text { Std. Err. } \\
\text { of the Est. }\end{array}$} & \multicolumn{3}{|c|}{$\begin{array}{l}\text { Change Statistics } \\
\end{array}$} \\
\hline & & & & & $\begin{array}{c}\text { R Sqr. } \\
\text { Chg. }\end{array}$ & F Chg. & Sig. F Chg. \\
\hline 1 & $.641(\mathrm{a})$ & .411 & .409 & .73185 & .411 & 281.391 & .000 \\
\hline 2 & $.641(\mathrm{~b})$ & .411 & .408 & .73232 & .001 & .485 & .486 \\
\hline 3 & $.646(\mathrm{c})$ & .417 & .412 & .72980 & .005 & 3.787 & .052 \\
\hline
\end{tabular}

a Predictors: (Constant), Observability

b Predictors: (Constant), Observability, Industry Type

c Predictors: (Constant), Observability, Industry Type, Interaction

As presented in Table 12, industry type does not moderate complexity on ICT adoption. However, a significant association exists between complexity and ICT adoption. Therefore, H5 is accepted.

Table 12: Industry Type with Complexity Models

\begin{tabular}{|c|c|c|c|c|c|c|c|}
\hline \multirow[t]{2}{*}{ Model } & \multirow[t]{2}{*}{$\mathbf{R}$} & \multirow[t]{2}{*}{ R Sqr. } & \multirow{2}{*}{$\begin{array}{l}\text { Adj. R } \\
\text { Sqr. }\end{array}$} & \multirow{2}{*}{$\begin{array}{l}\text { Std. Err. of } \\
\text { the Est. }\end{array}$} & \multicolumn{3}{|c|}{ Change Statistics } \\
\hline & & & & & $\begin{array}{l}\text { R Sqr. } \\
\text { Chg. }\end{array}$ & F Chg. & $\begin{array}{l}\text { Sig. F } \\
\text { Chg. }\end{array}$ \\
\hline 1 & $.082(\mathrm{a})$ & .007 & .004 & .95004 & .007 & 2.726 & .100 \\
\hline 2 & $.133(\mathrm{~b})$ & .018 & .013 & .94596 & .011 & 4.493 & .035 \\
\hline 3 & $.143(\mathrm{c})$ & .021 & .013 & .94572 & .003 & 1.204 & .273 \\
\hline
\end{tabular}

Table 13 indicates that industry type does not moderate security on ICT adoption although a significant association is recorded between security and ICT adoption. Therefore, H6 is accepted.

Table 13: Industry Type with Security Models

\begin{tabular}{|c|c|c|c|c|c|c|c|}
\hline \multirow[t]{2}{*}{ Model } & \multirow[t]{2}{*}{$\mathbf{R}$} & \multirow[t]{2}{*}{ R Sqr. } & \multirow{2}{*}{$\begin{array}{l}\text { Adj.R } \\
\text { Sqr. }\end{array}$} & \multirow{2}{*}{$\begin{array}{c}\text { Std. Err. } \\
\text { of the Est. }\end{array}$} & \multicolumn{3}{|c|}{$\begin{array}{l}\text { Change Statistics } \\
\end{array}$} \\
\hline & & & & & $\begin{array}{l}\text { R Sqr. } \\
\text { Chg. }\end{array}$ & F Chg. & $\begin{array}{l}\text { Sig. F } \\
\text { Chg. }\end{array}$ \\
\hline 1 & $.796(a)$ & .634 & .633 & .57679 & .634 & 699.434 & .000 \\
\hline 2 & $.802(\mathrm{~b})$ & .642 & .641 & .57071 & .009 & 9.651 & .002 \\
\hline 3 & $.802(\mathrm{c})$ & .643 & .640 & .57134 & .000 & .121 & .728 \\
\hline
\end{tabular}

a Predictors: (Constant), Security

b Predictors: (Constant), Security, Industry Type

c Predictors: (Constant), Security, Industry Type, Interaction 
Table 14 indicates that industry type does not moderate costs on ICT adoption, neither does a significant association exists between the two variables. Therefore, $\mathrm{H} 7$ is accepted.

Table 14: Industry Type with Cost Models

\begin{tabular}{|c|c|c|c|c|c|c|c|}
\hline \multirow[t]{2}{*}{ Model } & \multirow[t]{2}{*}{$\mathbf{R}$} & \multirow[t]{2}{*}{ R Sqr. } & \multirow[t]{2}{*}{ Adj. R Sqr. } & \multirow{2}{*}{$\begin{array}{l}\text { Std. Err. } \\
\text { of the Est. }\end{array}$} & \multicolumn{3}{|c|}{$\begin{array}{l}\text { Change Statistics } \\
\end{array}$} \\
\hline & & & & & R Sqr. Chg. & F Chg. & $\begin{array}{l}\text { Sig. F } \\
\text { Chg. }\end{array}$ \\
\hline 1 & $.399(\mathrm{a})$ & .159 & .157 & .87426 & .159 & 76.295 & .000 \\
\hline 2 & $.402(\mathrm{~b})$ & .162 & .158 & .87380 & .003 & 1.422 & .234 \\
\hline 3 & $.409(\mathrm{c})$ & .167 & .161 & .87195 & .006 & 2.715 & .100 \\
\hline
\end{tabular}

\section{Discussion and Implications}

The study has achieved its objectives by examining the moderating effect of industry type on the seven characteristics of technological innovation and ICT adoption which is largely scarce to date. The findings are beneficial to the policy makers in terms of the identification of important factors to be addressed when promoting ICT adoption among the SMEs. As for the SMEs, it provides them with relevant and useful information so as to mitigate their worries and fears over adopting ICT.

This study found that compatibility is the only characteristic moderated by industry type. This is not difficult to understand as an innovation is likely to be adopted if it is compatible with the job responsibilities and value systems of individuals (Tornatzky and Klein, 1982). The SMEs in this case might perceive that ICT adoption interrupts with their existing business processes rather than increases their efficiency and effectiveness which are the primary goals of the enterprises. Despite the significant relationship, it explains only $1.1 \%$ of the variance in ICT adoption. A conclusion can be safely drawn that industry type is not a significant moderating factor. Referring to the literature on the benefits to be attained from adopting ICT which is well-documented, the findings imply that ICT adoption is beneficial to all SMEs regardless of sectors. The findings suggest that SMEs must be innovative enough in addressing the turbulent business issues by embracing ICT as a way to complement their market offerings and strengthening their market positions irregardless of which industry type they belong to (Tan et. al., 2009a; Tan et. al., 2009b).

Although industry type does not moderate other independent variables on ICT adoption, relative advantage, compatibility, observability, security and cost are found directly and significantly influencing SMEs in adopting ICT. This finding implies that most SMEs regardless of industry type are directly influenced by ICT factors in ICT adoption decisions. The finding is consistent with prior studies (Aljitri et. al., 2003; Hoi et. al., 2003; Ratnasingam, 2001; Rose et. al., 1999) where many SMEs lack of confidence over security confidentiality over the current ecommerce set-up. This implies that the use of ICT should warrant users the safety, privacy and confidentiality of transactions sent and received through digital lines (Tan et. al., 2009b).

Similarly, complexity is found as another significant reason that hinders ICT adoption. This is expected as many SMEs require technical knowledge and expertise, which are lacking, in order to overcome the complexity of ICT (Duan et. al., 2002; Fulantelli and Allgera, 2003; Hashim, 2007; Jones et. al., 2003; Khatibi et. al., 2003; Kogilah et. al., 2008; Tan et. al., 2009b). As such, this calls for the SMEs to hire the right technical personnel and to provide proper training to all staff to utilise ICT. Many of them are unaware that there are many training programmes offered by government agencies such as the National Productivity Corporation and various skills development centres. Many of these programmes are funded and therefore, cost of training is not a significant issue.

Finally, trialability has been identified as another major reason for the SMEs not to adopt ICT. This finding can be explained from the misconceptions that arise among the SMEs that trial software is not available in Malaysia and therefore, they will have to resort into using pirated software which is a major concern for these SMEs going online. It was reported that $50 \%$ of the companies raided in Malaysia in 2006 using pirated software were SMEs (Amis, 
2007). Trialability is also a major concern for enterprises intending to use genuine software. The findings suggest that it is imperative to provide these enterprises with information on the availability of trial software. Many of the enterprises are not aware that many ICT firms, particularly the Multimedia Super Corridor status firms are actively offering trial versions of software which allow the SMEs to try them before making a purchase decision. As a matter of fact, many of these software programmes can be tailored towards meeting the specific requirements of the SMEs (Tan et. al., 2009b).

\section{Limitations and Suggestions for Future Research}

Even though the sample size obtained in this study is rather large, the study focuses only on SMEs located in the states of Melaka and Johor. This restricts the generalisability of the results obtained. Future studies should consider all the regions in Malaysia. It is also possible to conduct similar study on all the industry types in Malaysia. Cross-cultural studies are also possible to see whether the results are similar or otherwise.

Although this study extends the DOI model, it focuses only on one moderating effect, i.e. industry type. Other important moderating variables such as year of business start-up, individual characteristics of owners and/or managers, annual sales turnover and Internet experience are not covered. The inclusion of these variables in future studies is therefore warranted. It is also interesting to see more characteristics being incorporated in the DOI model, such as government policies and network infrastructure which may portray significant results.

\section{Conclusion}

This study has built upon literature on the moderating effect of industry types on the characteristics of technological innovation and ICT adoption which is scarce to date. From the research perspectives, the use of extended DOI model has enhanced our understanding of the possibility of extending the currently available technology adoption and acceptance models although few significant relationships are observed. From the practical perspective, significant concerns faced by Malaysian SMEs are identified and discussed. It is therefore hoped that the recommendations shed some lights to the SMEs in allaying their worries and fears of adopting ICT. The government has played its role to promote ICT and it is imperative that the SMEs reciprocate in order to achieve their business goals.

\section{References}

Abouzeedan, A., \& Busler, M. (2002), 'Information Technology (IT) Impact on Performance of Small and Medium Enterprises (SMEs),' Proceedings of RENT XVI, Research in Entrepreneurship and Small Business, Barcelona, Spain, 127-156.

Ajzen, I., \& Fishbein, M. (1980) Understanding Attitudes and Predicting Social Behavior. Englewood Cliffs, NJ: Prentice-Hall.

Aljitri, H.A., Pons, A., \& Collins, D. (2003), 'Global E-Commerce: A Framework for Understanding and Overcoming the Trust Barrier,' Information Management, 11(3), 130-138.

Allan, C., Annear, J., Beck, E., \& Beneren, J. V. (2003), 'A Framework for the Adoption of ICT and Security Technologies by SMEs', Proceedings of the $16^{\text {th }}$ Annual Conference of Small Enterprise Association of Australia and New Zealand, 1-10.

Anis, M.N. (2007), 'SMEs Among Main Pirated Software Users,' The Star Online. [Online], [Retrieved April 17, 2007], http://startechcentral.com/tech/story.asp?file=/2007/4/1 $7 /$ technology $/ 20070417104725 \&$ sec =technolo gy

Asia Foundation (2002), 'Regional Survey of SMEs' Use of E-commerce in Indonesia, the Philippines, Sri Lanka, and Thailand'. [Online], [Retrieved April 19, 2007], http://www.asiafoundation.org/ICT/surveys.ht $\mathrm{ml}$

Beale, M.W. (1999), 'Consumer Concern over Ecommerce Security', E-Commerce Times.

[Online], [Retrieved April 20, 2007], http://www.ecommercetimes.com/story/ 1981.html.

Benham, H.C., \& Raymond, B.C. (1996), 'Information Technology Adoption: Evidence from a Voice Mail Introduction,' ACM SIGCPR Computer Personnel, 7(1), 3-25. 
Bhimani, A. (1996), 'Securing the Commercial Internet,' Communications of the ACM, 39(6), 29-35.

Carter, L., \& Belanger, F. (2004), 'The Influence of Perceived Characteristics of Innovating on eGovernment Adoption,' Electronic Journal of EGovernment, 2(1), 11-20.

Cooper, R.C., \& Schindler, P.S. (2003), Business Research Methods. New York: McGraw- Hill.

Cooper, R.B., \& Zmud, R.W. (1990), 'Information Technology Implementation Research: A Technological Diffusion Approach,' Management Science, 36(2), 123-139.

Davis, F.D. (1989), 'Perceived Usefulness, Perceived Ease of Use, and User Acceptance of Information Technology,' MIS Quarterly, 13(3), 319-339.

Duan, Y., Roisin, M., David, H., Stanislaw, S., Henry, S., Virgilio, M., \& Joao, A. (2002), 'Addressing ICT Skill Challenges in SMEs: Insights from Three Country Investigations,' Journal of European Industrial Training, 26(9), 430-441.

Ernst and Young (2001), 'Advancing with ECommerce', [Online], [Retrieved April 25, 2007], http://www.noie.gov.au.

Fink, D., \& Disterer, G. (2006), 'International Case Study: To What Extent is ICT Infused into the Operations of SMEs?,' Journal of Enterprise Information Management, 19(6), 608-624.

Fulantelli, G., \& Allgera, M. (2003), 'Small Company Attitude Towards ICT-Based Solutions: Some Key Elements to Improve It,' Educational Technology \& Science, 6(1), 45-49.

Gharavi, H., Love, E.D., \& Cheng, W.L. (2004), 'Information and Communication Technology in the Stockbroking Industry: An Evolutionary Approach to the Diffusion of Innovation,' Industrial Management \& Data Systems, 104(9), 756-765.

Gopal, M.H. (1970), An Introduction of Research Procedure in Social Science. Bombay: Asia Publishing House.

Hashim, J. (2007), 'Information Communication Technology (ICT) Adoption among Owners in
Malaysia', International Journal of Business and Information, 2(2), 221-240.

Hill, C.W.L., \& Jones, G.R. (2001), Strategic Management - An Integrated Approach. Boston: Houghton Mifflin Company.

Hoi, J.Y.Y., Shim, J.P., \& Yin, A.K.L. (2003), 'Current Progress of E-Commerce Adoption: Small and Medium Enterprises in Hong Kong,' Communications of the ACM, 46(9), 226-232.

James, J. (2003), 'Sustainable Internet Access for the Rural Poor? Elements of an Emerging Indian Model,' Futures, 35(5), 76-88.

Jones, P., Davies, P.B., \& Muir, E. (2003), 'EBusiness Barriers to Growth within the SME Sector,' Journal of Systems \& Information Technology, 7(1), 1-25.

Kendall, J.D., Tung, L., Chua K., Ng, D., \& Tan, S. (2001), 'Receptivity of Singapore's SMEs to Electronic Commerce Adoption,' Journal of Strategic Information Systems, 10, 223-242.

Khalifa, M., \& Cheng, S.K.N. (2002), 'Adoption of Mobile Commerce: Role of Exposure,' Proceedings of the $35^{\text {th }}$ Hawaii International Conference on System Sciences, 46-56.

Khatibi, A., Thyagarajan, V., \& Seetharaman, A. (2003). "E-Commerce in Malaysia: Perceived Benefits and Barriers,' Vikalpa, 28(3), 77-82.

Kogilah, N., Santhapparaj, A.S., \& Eze, U.C. (2008), 'An empirical study of website adoption among small and medium enterprises in Malaysia", Proceedings of the 10th IBIMA Conference on Innovation and Knowledge Management in Business Globalisation, 339-351.

Kotelnikov, V. (2007) Small and Medium Enterprises and ICT. Thailand: United Nations Development Program-Asia Pacific Development Information Program and Asian and Pacific Training Centre for Information and Communication Technology for Development.

Leong, H.Y., \& Wong, Y.S. (2007), 'SME Contribution to GDP Expected to Increase,' The Star Online. [Online], [Retrieved September 13, 2007], http://startechcentral.com/tech/story.asp?file=/2007/9/1 $3 /$ sme $/ 20070913104832 \&$ sec $=$ sme 
Levy, M., Powell, P., \& Worrall, L. (2005), 'Strategic Intent and E-Business in SMEs: Enablers and Inhibitors,' Information Resources Management Journal, 18(4), 1-20.

Light, D. A. (2001), 'Sure, You Can Trust Us,' Sloan Management Review, 43(1), 17-18.

Limthongchai, P., \& Speece, M.W. (2003), 'The Effect of Perceived Characteristics of Innovation on E-Commerce Adoption by SMEs in Thailand,' Proceedings of the Seventh International Conference on Global Business and Economic Development, 1573-1585.

McCloskey, D. (2004) 'Evaluating Electronic Commerce Acceptance with the Technology Acceptance Model,' Journal of Computer Information Systems, 44(2), 49-57.

Mendo, F.A., \& Fitzgerald, G. (2005). 'A Multidimensional Framework for SME Ebusiness Progression,' Journal of Enterprise Information Management, 18(6), 678-696.

National SME Development Council (NSDC) (2005) SME Annual Report: Optimising Strategic Values. Malaysia: Bank Negara Malaysia.

National SME Development Council (2006) SME Annual Report: Progressive and Innovative. Malaysia: NSME.

Organisation for Economic Corporation and Development (OECD) (2000) Enhancing the Competitiveness of SMEs in the Global Economy: Strategies and Policies. Paris: OECD.

Raj, S. (2007), "Nurturing Start-ups", TheStar Online. [Online], [Retrieved March 26, 2007], http://star-

techcentral.com/tech/story.asp?file $=/ 2007 / 3 / 2$ $6 / \mathrm{sme} / 20070326124932 \& \mathrm{sec}=$ sme

Rashid, M.A., \& Al-Qirim, N.A. (2001), 'ECommerce Technology Adoption Framework by New Zealand Small to Medium Size Enterprises,' Research Letters in the Information and Mathematical Sciences, 2, 63-70.

Ratnasingam, P. (2001) 'Electronic Commerce Adoption in Australia and New Zealand,' Malaysia Journal of Computer Sciences, 14(1), 223-242.

Rogers, E.M. (1983) Diffusion of Innovations. New York: The Free Press.
Rogers, E.M. (1996) Communication Technology: The New Media Society. New York: Free Press.

Rose, G., Khoo, H., \& Straub, D. (1999), 'Current Technological Impediments to Business-toConsumer Electronic Commerce,' Communications of the Association for Information Systems, 1(16), 1-74.

Sambrook, S. (2003) 'E-Learning in Small Organisations,' Education + Training, 45(8/9), 506-516.

Sekaran, U. (2003) Research Methods for Business: A Skill Building Approach. New York: John Wiley \& Sons.

Slegers, C., Singh, S., \& and Hall, J. (1998) Small Business and Electronic Commerce: An Australian Survey. RMIT University: Center for International Research on Communication and Information Technologies.

Tan, K.S., Chong, S.C., \& Eze, U.C. (2009a), 'Factors Influencing Internet-based ICT Adoption among Malaysian SMEs,' International Journal of Management and Enterprise Development, 6(4), 397-418.

Tan, K.S., Chong, S.C., Lin, B., \& Eze, U.C. (2009b), 'Internet-based ICT Adoption among Small and Medium Enterprises: Malaysia's Perspective,' Industrial Management \& Data Systems, 109(2), 224-244.

Tan, K.S. Chong, S.C., Lin, B., \& Eze, U.C. (2009), 'Internet-based ICT Adoption among SMEs: Demographic versus Benefits, Barriers, and Adoption Intention,' Journal of Enterprise Information Management, 23(1), 27-55.

Tan, K.S., \& Eze, U.C. (2008), 'An Empirical Study of Internet-Based ICT Adoption Among Malaysian SMEs,' Communications of the IBIMA, 1(1), ISSN: 1943-7765.

Tan, M., \& Teo, T.S.H. (2000,) 'Factors Influencing the Adoption of Internet Banking,' Journal of the Association for Information Systems, 1(5), 1-42.

Tornatzky, L.G., \& Klein, K.J. (1982) 'Innovation Characteristics and Innovation-Implementation: A Meta-Analysis of Findings,' IEEE Transactions on Engineering Management, 29(1), 28-45. 
Vidgen, R., Francis, D., Powell, P., \& Woerndl, M. (2004) 'Web Service Business Transformation: Collaborative Commerce Opportunities in SMEs,' Journal of Enterprise Information Management, 17(5), 372-381.

Yeung, J.H.Y., Shim, J.P., \& Lai, A.Y.K. (2003), 'Current Progress of E-Commerce Adoption: Small and Medium Enterprises in Hong Kong,' Communication of the ACM, 46(9), 226-232. 